\title{
Pengaruh Waktu Aging dan Metode Ekstraksi terhadap Aktivitas Antioksidan Black Garlic yang Dibandingkan dengan Bawang Putih (Allium sativum L.)
}

\author{
Salma Fadhilah Azhar", Kiki Mulkiya Yuliawati
}

Prodi Farmasi, Fakultas Matematika dan Ilmu Pengetahuan Alam, Universitas Islam Bandung, Indonesia.

*salmafazhar@gmail.com, qqmulkiya@gmail.com

\begin{abstract}
Antioxidant is a compound that could obstruct oxidation reaction through free radical binding. Garlic (Allium sativum L.) is a plant which has many benefits that could be used for traditional medication. Some of pharmacology effects which was discovered are antioxidant, anti-hypertensive, anti-cholesterol, and antimicrobial. Black garlic is the heating aging process which induces many chemical reactions of garlic such as non-enzymatically discoloration to be brown, Maillard reaction which produces antibacterial compound, caramelization, and phenol formation as antioxidant that causes discoloration from cream to dark brown or black. White and Black garlic were extracted through two methods, namely maceration (room temperature) and digestion $\left( \pm 40^{\circ} \mathrm{C}\right.$ ) by using $96 \%$ ethanol solvent. The activity test of extract antioxidant is done using DPPH free radical reduction (2,2-difenil-1-pikrilhidrazil) with absorbance measurement uses UV-Vis spectrophotometry with DPPH maximum wavelength is $515 \mathrm{~mm}$. Garlic maceration has value IC50 in the amount of $28.422 \mathrm{ppm}$, two weeks maceration of black garlic in the amount of $27.129 \mathrm{ppm}$ and four weeks maceration of black garlic in the amount of $13.041 \mathrm{ppm}$. While garlic digestion in the amount of 28.524 ppm, two weeks digestion of black garlic in the amount of 28.086 $\mathrm{ppm}$ and four weeks digestion of black garlic in the amount of $15.160 \mathrm{ppm}$.
\end{abstract}

Keywords: Allium sativum L., black garlic, ethanol, methanol, DPPH.

\begin{abstract}
Abstrak. Antioksidan merupakan senyawa yang dapat menghambat reaksi oksidasi, dengan cara mengikat radikal bebas. Bawang putih (Allium sativum L.) merupakan salah satu tanaman yang mempunyai banyak khasiat yang digunakan untuk pengobatan tradisional. Efek farmakologi yang telah diketahui salah satunya adalah antioksidan, anti-hipertensi, anti-kolesterol, anti-mikroba. Bawang hitam merupakan proses aging dengan pemanasan yang menginduksi banyak reaksi kimia pada bawang putih seperti perubahan warna menjadi coklat secara non-enzimatik, reaksi Maillard yang menghasilkan senyawa antibakteri, karamelisasi, dan pembentukan fenol sebagai antioksidan yang menyebabkan warnanya berubah dari putih kekuningan menjadi coklat tua atau hitam. Bawang putih dan bawang hitam diekstraksi menggunakan dua metode yaitu maserasi (suhu kamar) dan digesti (suhu $\pm 40^{\circ} \mathrm{C}$ ) dengan menggunakan pelarut etanol $96 \%$. Uji aktivitas antioksidan ekstrak dilakukan dengan menggunakan metode peredaman radikal bebas DPPH (2,2-difenil-1-pikrilhidrazil) dengan pengukuran absorbansi menggunakan spektrofotometri UV-Vis pada panjang gelombang maksimal DPPH yaitu $515 \mathrm{~nm}$. Pada bawang putih maserasi memiliki nilai IC50 sebesar 28,422 ppm, bawang hitam 2 minggu maserasi 27,129 ppm dan bawang hitam 4 minggu maserasi 13,041 ppm. Sedangkan pada bawang putih digesti 28,524 ppm, bawang hitam 2 minggu digesti 28,086 ppm dan bawang hitam 4 minggu digesti $15,160 \mathrm{ppm}$.
\end{abstract}

Kata Kunci: Allium sativum L., bawang hitam, etanol, metanol, DPPH. 


\section{A. Pendahuluan}

Antioksidan merupakan senyawa yang dapat menghambat reaksi oksidasi, dengan cara mengikat radikal bebas dan molekul yang sangat reaktif (Winarsi, 2007 : 11 - 12). Serangan radikal bebas terhadap molekul sekelilingnya akan menyebabkan terjadinya reaksi berantai, yang kemudian menghasilkan senyawa radikal baru. Dampak reaktivitas senyawa radikal bebas mulai dari kerusakan sel atau jaringan, penyakit autoimun, penyakit degeneratif, hingga kanker (Sadikin, 2001).

Bawang putih (Allium sativum L.) merupakan salah satu tanaman yang mempunyai banyak khasiat yang digunakan untuk pengobatan tradisional. Efek farmakologi yang telah diketahui antara lain adalah antioksidan, anti-hipertensi, anti-kolesterol, anti-mikroba.

Black Garlic merupakan hasil pengolahan terhadap bawang putih melalui proses aging dengan suhu $70^{\circ} \mathrm{C}$ dan kelembaban $70 \%$ - 80\% selama 30 sampai 40 hari tanpa penambahan zat lain maupun perlakuan tambahan apapun dan proses ini dinamakan proses aging (Wang, dkk., 2012). Pada proses aging tersebut terjadi suatu reaksi yang bernama reaksi Maillard. Reaksi Maillard dapat menyebabkan perubahan warna, bau, serta rasa asli pada bawang putih (Hanny, $2018: 4$ ).

Perubahan karakteristik yang terjadi pada proses tersebut adalah perubahan warna bawang putih menjadi hitam, rasa bawang menjadi manis serta bau menyengat pada bawang sudah tidak lagi tercium (Choi, S. et al., 2014). Selain itu, salah satu senyawa metabolit sekunder yang berperan sebagai antioksidan adalah polifenol. Proses aging menyebabkan peningkatan senyawa polifenol yang terkandung didalam Black Garlic, sehingga kekuatan antioksidan pada Black Garlic lebih kuat dibandingkan pada bawang putih biasa (Choi, Duk Ju., et al., 2008).

Proses aging dengan pemanasan menginduksi banyak reaksi kimia pada bawang putih seperti perubahan warna menjadi coklat secara non-enzimatik, reaksi Maillard yang menghasilkan senyawa antibakteri, karamelisasi, dan pembentukan fenol sebagai antioksidan yang menyebabkan warnanya berubah dari putih kekuningan menjadi coklat tua atau hitam (Hanny, 2018 : 4).

\section{B. Landasan Teori}

Bawang putih adalah tanaman dari Allium sekaligus nama dari umbi yang dihasilkan. Umbi dari tanaman bawang putih merupakan bahan utama untuk bumbu dasar masakan Indonesia (Rahmawati, 2012 : 1). Kandungan metabolit sekunder yang terdapat di dalam bawang putih membentuk suatu sistem kimiawi yang kompleks serta merupakan mekanisme pertahanan diri dari kerusakan akibat mikroorganisme dan faktor eksternal lainnya (Amagase et al., 2001 : 959). Dua senyawa organosulfur paling penting dalam bawang putih, yaitu asam amino nonvolatil $\gamma$-glutamil-Salk(en)il-L-sistein dan minyak atsiri S-alk(en)ilsistein sulfoksida atau alliin (Ellmore dan Feldberg, 1994 : 89).

Black garlic adalah bawang putih segar yang dipanaskan pada suhu tinggi selama dua sampai empat minggu sehingga menghasilkan bawang hitam dengan rasa yang manis. Pengolahan dengan metode pemanasan tidak akan mengurangi kandungan antioksidan pada bawang putih (Wang et al., $2010: 37$ ).

Selama Proses aging senyawa allisin yang terkandung didalam Black Garlic berubah menjadi komponen antioksidan diantaranya adalah SAC (S-allyl cysteine), alkaloid dan flavonoid. Ketiga senyawa tersebut terbentuk melalui proses pemanasan (Rouzni, 2018 : 35). Kandungan senyawa yang bersifat sebagai antioksidan pada Black Garlic diantaranya adalah Sallyl sistein (SAC), asam fenolik dan flavonoid. Jumlah SAC dalam Black Garlic lima sampai enam kali lebih tinggi daripada bawang putih segar. Bawang putih segar mengandung $\gamma$ glutamyl-S-allylcysteine yang dapat dihidrolisis dan dioksidasi untuk membentuk alliin. Alliin dikonversi menjadi allicin oleh allinase setelah melalui proses penghancuran, memotong, mengunyah, ataupun pemanasan. Pemanasan akan menyebabkan perubahan GSAC $(\gamma-$ Glutamyl-S-allylcysteine) menjadi SAC (S-allyl cysteine) (Choi, Duk Ju et al, 2008).

Ekstrak Black Garlic diketahui memiliki aktivitas anti-bakteri, antioksidan, antidiabetes, antiinflamasi. Namun, aktivitas tersebut menunjukkan efektivitas yang berbeda-beda 
tergantung kondisi aging (Hanny, $2018: 4$ ).

Maserasi merupakan cara penyarian yang sederhana. Maserasi dilakukan dengan cara merendam serbuk simplisia dalam cairan penyari. Cairan penyari akan menembus dinding sel dan masuk ke dalam rongga sel yang mengandung zat aktif, zat aktif akan larut dan karena adanya perbedaan konsentrasi antara larutan zat aktif di dalam dengan yang di luar sel, maka larutan yang terpekat didesak keluar. (Dirjen POM, 1986: 16-22).

Digesti merupakan maserasi menggunakan pemanasan lemah $\left(40-50^{\circ} \mathrm{C}\right)$. Metode digesti memiliki keuntungan yaitu kemampuan cairan penyari untuk melarutkan zat diinginkan menjadi lebih besar dan memiliki pengaruh sama dengan pengadukan, kekentalan pelarut berkurang yang dapat mengakibatkan berkurangnya lapisan batas. Pada umumnya kelarutan zat akan meningkat sejalan dengan kenaikan suhu (I Gusti, $2010: 8$ ).

Antioksidan adalah senyawa yang mempunyai struktur molekul yang dapat memberikan elektronnya kepada molekul radikal bebas tanpa terganggu sama sekali fungsinya dan dapat memutuskan reaksi berantai dari radikal bebas. DPPH (1,1-difenil-2- pikrilhidrazil). Interaksi antioksidan dengan DPPH baik secara transfer elektron atau radikal hidrogen pada DPPH akan menetralkan karakter radikal bebas dari DPPH. Metode peredaman radikal bebas DPPH didasarkan pada reduksi dari larutan methanol radikal bebas DPPH yang berwarna oleh penghambatan radikal bebas. Ketika larutan DPPH yang berwarna ungu bertemu dengan bahan pendonor elektron maka DPPH akan tereduksi, menyebabkan warna ungu akan memudar dan digantikan warna kuning yang berasal dari gugus pikril. (Prayoga, 2013).

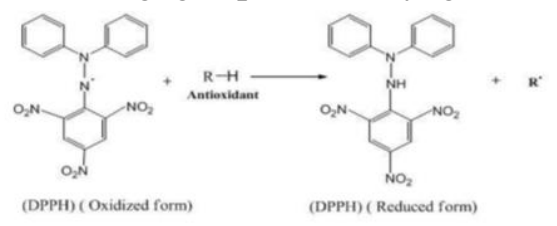

Gambar 1.

Suatu senyawa dikatakan sebagai antioksidan sangat kuat jika nilai IC50 kurang dari 50, kuat (50-100), sedang (100-150), dan lemah (151-200). Semakin kecil nilai IC50 semakin tinggi aktivitas antioksidan. (Badarinath, 2010 : 1276). IC50 adalah konsentrasi suatu senyawa yang menyebabkan penghambatan sebesar 50\% terhadap sebuah sistem yang diberikan. Dengan demikian untuk aktivitas penangkal radikal bebas DPPH nilai IC50 dapat diartikan sebagai konsentrasi ekstrak yang menyebabkan penurunan konsentrasi DPPH sebesar 50\% dari konsentrasi DPPH awal (Andi, dkk., 2013 : 164).

\section{Metodologi}

Pengujian aktivitas antioksidan dari ekstrak Black Garlic dan bawang putih (Allium sativum L.) dilakukan secara in vitro menggunakan spektrofotometri UV-Vis. Sampel penelitian berupa bawang putih (Allium sativum L.) yang diperoleh dari Pasar Induk Gede Bage di Kota Bandung, Jawa Barat. Bawang putih kemudian dideterminasi di Herbarium Bandungense Sekolah Ilmu dan Teknologi Hayati Institut Teknologi Bandung. Dilakukan proses aging pada bawang putih segar selama 2 minggu dan 4 minggu. Selanjutnya diuji penentuan parameter standarnya meliputi parameter spesifik dan non-spesifik, serta diuji penapisan fitokimia. Kemudian diekstraksi menggunakan dua metode yaitu maserasi dan digesti (suhu $\pm 40^{\circ} \mathrm{C}$ ) dengan menggunakan pelarut etanol 96\%. Pengujian parameter standar ekstrak meliputi uji bobot jenis serta penapisan fitokimia terhadap ekstrak. Uji aktivitas antioksidan ekstrak Black Garlic menggunakan metode peredaman radikal bebas DPPH dengan pengukuran absorbansi ekstrak Black Garlic menggunakan spektrofotometri UV-Vis pada panjang gelombang maksimal $515 \mathrm{~nm}$. Uji aktivitas antioksidan dilakukan terhadap vitamin C sebagai pembanding.

\section{Hasil Penelitian dan Pembahasan}

Determinasi Bahan

Determinasi ini dilakukan untuk mengetahui kebenaran spesies dan identitas tumbuhan se- 
spesifik mungkin. Dengan demikian kesalahan dalam pengumpulan bahan yang akan diteliti dapat dihindari. Hasil determinasi yang menunjukan bahwa tumbuhan tersebut dinyatakan benar merupakan umbi bawang putih dengan nama latin Allium Sativum L.

\section{Proses Aging Bawang Putih}

Bawang putih yang telah dideterminasi kemudian diberi perlakuan proses aging menggunakan alat penanak nasi. Sebelum itu, bawang putih terlebih dahulu di bungkus menggunakan alumunium foil agar suhu bawang tetap terjaga serta menghindari terkena tetesan air dari uap yang dihasilkan oleh penanak nasi tersebut.

Waktu proses aging yang dilakukan yaitu pada 2 minggu dan 4 minggu, hal ini dipilih karena pada rentang waktu tersebut merupakan waktu yang umum digunakan masyarakat untuk melakukan proses aging pada bawang putih menjadi bawang hitam. Selama proses aging senyawa allisin yang terdapat pada bawang putih berubah menjadi komponen antioksidan seperti S-allyl cystein (SAC), alkaloid dan flavonoid (Rouzni, 2018 : 34). Proses pemanasan menginduksi banyak reaksi kimia pada bawang putih seperti pencokelatan secara nonenzimatik atau juga disebut sebagai reaksi Maillard. Reaksi Maillard merupakan reaksi yang terjadi antara gula pereduksi dengan gugus amina (Made, 2016 : 6). Selain itu, reaksi Maillard menyebabkan karamelisasi pada bawang hitam.

Selama proses pemanasan, rasa dan bau tidak menyenangkan yang terkandung dalam bawang putih mentah diubah menjadi senyawa tidak berbau. Akibatnya bawang hitam umumnya memiliki rasa asam, manis dan sedikit agak kelat. Namun, apabila suhu yang digunakan selama proses aging terlalu tinggi ataupun waktu aging yang terlalu lama, maka akan dapat menurunkan kualitas dari bawang hitam karena enzim yang terkandung dalam bawang hitam sangat sensitif dan labil terhadap perubahan suhu, hal ini dapat memicu terjadinya kerusakan pada bawang hitam.

\section{Pembuatan Simplisia}

Metode pengeringan ini dilakukan bertujuan agar senyawa yang terkandung di dalam bawang tidak rusak karena terpapar suhu tinggi. Selain itu, pengeringan dilakukan bertujuan untuk mencegah proses reaksi enzimatik yang dapat terjadi pada bawang sehingga kandungan senyawa yang terdapat pada bawang tidak akan berubah atau terpengaruh serta untuk mengurangi kadar air yang terkandung pada bawang sehingga menjadi simplisia yang tidak mudah rusak, tidak mudah busuk dan tidak tercemar mikroba, serta dapat disimpan dalam waktu yang lama.

\section{Parameter Spesifik dan Non Spesifik}

1. Parameter Spesifik

Tujuan dari pemeriksaan mikroskopik serbuk simplisia adalah untuk memperoleh identitas simplisia. Pada pemeriksaan ini dilakukan dengan perbesaran lensa sebesar 40x. Hasil mikroskopik dapat dilihat sebagai berikut :

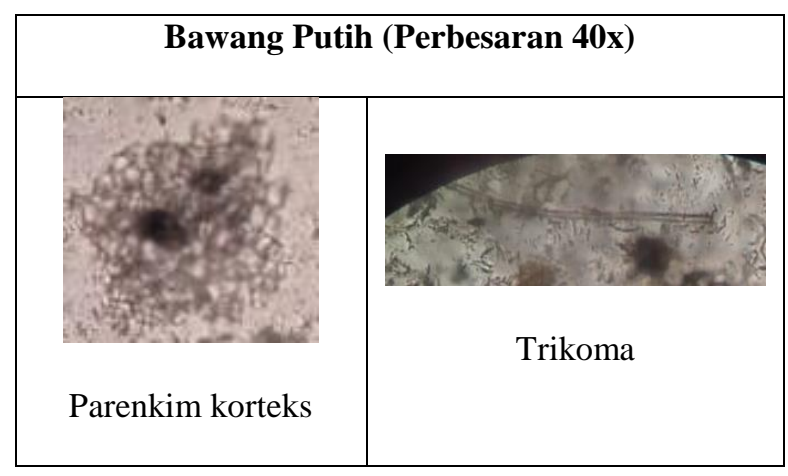




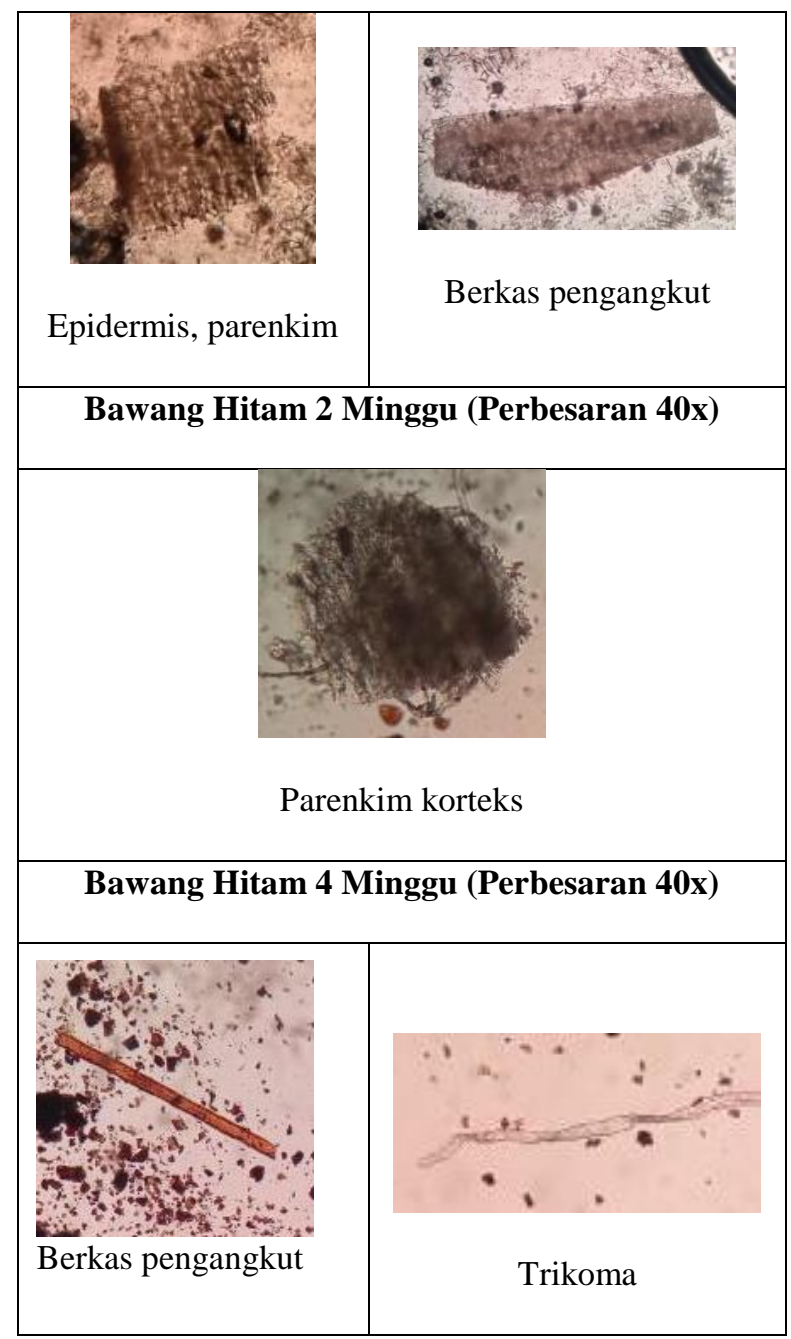

Tabel 1. Hasil Parameter Spesifik Kadar Sari Larut Etanol dan Air

\begin{tabular}{|c|c|c|}
\hline Parameter Spesifik & Simplisia & $\begin{array}{c}\text { Hasil Rata- } \\
\text { rata } \\
\end{array}$ \\
\hline \multirow{3}{*}{ Kadar Sari Larut Etanol } & Bawang Putih & $20.19 \%$ \\
\hline & Bawang Hitam 2 Minggu & $67.34 \%$ \\
\hline & Bawang Hitam 4 Minggu & $52.14 \%$ \\
\hline \multirow{3}{*}{ Kadar Sari Larut Air } & Bawang Putih & $67.37 \%$ \\
\hline & Bawang Hitam 2 Minggu & $66.15 \%$ \\
\hline & Bawang Hitam 4 Minggu & $50.62 \%$ \\
\hline
\end{tabular}

Dari hasil berikut yang diperoleh nilai kadar sari larut etanol lebih tinggi ditunjukkan oleh bawang hitam, sedangkan nilai kadar sari larut air lebih tinggi ditunjukkan oleh bawang putih Hal ini dikarenakan senyawa yang terkandung dalam bawang cenderung bersifat polar, sedangkan pada bawang hitam lebih tertarik pada pelarut yang memiliki sifat cenderung semi polar seperti etanol. 
2. Parameter Non-Spesifik

\begin{tabular}{|c|c|c|}
\hline Parameter Non Spesifik & Simplisia & $\begin{array}{c}\text { Hasil } \\
\text { Rata-rata } \\
\end{array}$ \\
\hline \multirow{3}{*}{ Susut Pengeringan } & Bawang Putih & $6.357 \%$ \\
\hline & Bawang Hitam 2 Minggu & $8.997 \%$ \\
\hline & Bawang Hitam 4 Minggu & $8.420 \%$ \\
\hline \multirow{3}{*}{ Kadar Air } & Bawang Putih & $6.25 \%$ \\
\hline & Bawang Hitam 2 Minggu & $8.75 \%$ \\
\hline & Bawang Hitam 4 Minggu & $8.00 \%$ \\
\hline \multirow{3}{*}{ Kadar Abu Total } & Bawang Putih & $4.755 \%$ \\
\hline & Bawang Hitam 2 Minggu & $3.612 \%$ \\
\hline & Bawang Hitam 4 Minggu & $5.137 \%$ \\
\hline \multirow{3}{*}{ Kadar Abu Tidak Larut A sam } & Bawang Putih & $0.725 \%$ \\
\hline & Bawang Hitam 2 Minggu & $0.440 \%$ \\
\hline & Bawang Hitam 4 Minggu & $0.750 \%$ \\
\hline
\end{tabular}

Tabel 4. 2 Hasil Parameter Non Spesifik

Parameter susut pengeringan memberikan batasan maksimal tentang besarnya senyawa yang hilang dalam proses pengeringan. Menurut Kemenkes RI (2010) menyatakan bahwa susut pengeringan tidak boleh lebih dari $10 \%$.

Kadar air merupakan batasan besarnya kandungan air yang berada di dalam simplisia yang digunakan. Menurut Kemenkes RI (2010) menyatakan bahwa kadar air tidak boleh lebih dari $10 \%$.

Kadar abu memberikan gambaran kandungan mineral yang terkandung di dalam suatu simplisia. Menurut Depkes RI (1989) kadar abu total dalam bawang tidak oleh lebih dari 1\% dan kadar abu tidak larut air tidak lebih dari $1.5 \%$. Maka berdasarkan hasil yang diperoleh, kadar abu total tidak memenuhi persyaratan, hal ini dimungkinkan karena minggu masih terdapat pengotor.

\begin{tabular}{|c|c|c|}
\hline Metode Ekstraksi & Simplisia & BJ \\
\hline \multirow{3}{*}{ Maserasi } & Bawang Putih & 0.849 \\
\hline & Bawang Hitam 2 Minggu & 0.868 \\
\hline & Bawang Hitam 4 Minggu & 0.867 \\
\hline \multirow{3}{*}{ Digesti } & Bawang Putih & 0.854 \\
\hline & Bawang Hitam 2 Minggu & 0.854 \\
\hline & Bawang Hitam 4 Minggu & 0.861 \\
\hline
\end{tabular}

Tabel 4. 3 Hasil Parameter Non Spesifik BJ

Penetapan BJ dilakukan untuk mengetahui batasan besarnya massa per satuan volume.

\section{Penapisan Fitokimia}

Penapisan fitokimia dilakukan untuk mengetahui kandungan metabolit sekunder seperti alkaloid, flavonoid, polifenolat, kuinon, steroid, saponin, sesquiterpen dan tanin. Metabolit sekunder yang terdapat dalam simplisia berfungsi sebagai pertahanan diri tanaman tersebut.

Menurut Rinaldi (2014) menyatakan bahwa flavonoid, tanin, termasuk ke dalam senyawa polar, alkaloid termasuk ke dalam senyawa semi polar, dan steroid /terpenoid termasuk ke dalam senyawa non polar. Hasil yang diperoleh dari penapisan fitokimia simplisia dan ekstrak bawang putih, bawang hitam 2 minggu dan bawang hitam 4 minggu positif mengandung alkaloid, flavonoid, polifenolat, triterpenoid.

\section{Aktivitas Antioksidan}

Prinsip dari metode DPPH ini adalah kemampuan suatu seyawa untuk mengikat radikal bebas. Larutan DPPH yang telah dibuat kemudian dicampurkan dengan larutan ekstrak, lalu diamati penurunan nilai absorbansinya. Larutan DPPH bertindak sebagai radikal bebas yang akan diredam oleh sampel uji. Saat sampel dan DPPH dicampurkan, terjadi reaksi yang merubah 
warna DPPH dari warna ungu menjadi pudar dan agak kekuningan. Perubahan ini terjadi karena DPPH di reduksi sehingga menyebabkan elektron bebas menjadi berpasangan.

Pengujian aktivitas antioksidan menggunakan spektrofotometri UV-Sinar Tampak karena struktur DPPH yang memiliki gugus kromofor dan auksokrom, larutan DPPH memiliki warna dan panjang gelombang DPPH berkisar di 515nm. Adapun vitamin C digunakan sebagai pembanding.

Pengujian dilakukan dengan cara membuat larutan induk DPPH konsentrasi 60 ppm dalam ruangan gelap karena larutan DPPH sangat peka terhadap cahaya, sangat tidak stabil dan mudah rusak. Kemudian pembuatan sempel dalam beberapa konsentrasi. Pengukuran absorbansi dilakukan dengan cara mencampurkan sampel dengan larutan DPPH pada perbandingan 1:1, kemudian di vortex beberapa saat agar homogen, setelah itu kedua campuran larutan diinkubasi pada suhu $37^{\circ} \mathrm{C}$ selama 30 menit. Waktu inkubasi ini merupakan operating time, operating time merupakan waktu yang dibutuhkan suatu senyawa untuk bereaksi dengen senyawa lain. $\mathrm{IC}_{50}$ menunjukan kemampuan sampel yang digunakan dalam mereduksi aktivitas DPPH sebesar $50 \%$.

\begin{tabular}{|c|c|c|c|}
\hline S axpel Uji & $\begin{array}{c}\text { Kons entrasi } \\
\text { (pmm) }\end{array}$ & $\begin{array}{r}\text { Rata-rata } \\
\% \text { Inhibisi } \\
\end{array}$ & $\begin{array}{r}\text { IC50 } \\
\text { (mmm) }\end{array}$ \\
\hline Vitamin $C$ & $\begin{array}{c}2 \\
4 \\
6 \\
8 \\
10\end{array}$ & $\begin{array}{l}42.539 \% \\
42.897 \% \\
46.547 \% \\
50.397 \% \\
57.261 \%\end{array}$ & 7.121 \\
\hline Bawang Putih (Mas erasi) & $\begin{array}{c}5 \\
15 \\
25 \\
35 \\
50\end{array}$ & $\begin{array}{l}45.868 \% \\
46.239 \% \\
48.978 \% \\
51.671 \% \\
54.735 \%\end{array}$ & 28.422 \\
\hline Bawang Putih (Digesti) & $\begin{array}{c}5 \\
15 \\
25 \\
35 \\
50\end{array}$ & $\begin{array}{l}40.706 \% \\
45.893 \% \\
49.784 \% \\
51.441 \% \\
57.709 \%\end{array}$ & 28.524 \\
\hline Black Garlic 2 (Mas erasi) & $\begin{array}{c}5 \\
15 \\
25 \\
35 \\
50\end{array}$ & $\begin{array}{l}41.198 \% \\
45.641 \% \\
49.119 \% \\
55.825 \% \\
56.244 \%\end{array}$ & 27.129 \\
\hline Black Garlic 2 (Dig esti) & $\begin{array}{c}5 \\
15 \\
25 \\
35 \\
50\end{array}$ & $\begin{array}{l}47.066 \% \\
49.581 \% \\
50.125 \% \\
50.419 \% \\
51.802 \% \\
\end{array}$ & 28.086 \\
\hline Black Garlie 4 (Mas erasi) & $\begin{array}{c}5 \\
15 \\
25 \\
35 \\
50\end{array}$ & $\begin{array}{l}48.533 \% \\
50.377 \% \\
51.425 \% \\
51.550 \% \\
52.472 \%\end{array}$ & 13.041 \\
\hline Black Gartic 4 (Digesti) & $\begin{array}{c}5 \\
15 \\
25 \\
35 \\
50\end{array}$ & $\begin{array}{l}42.712 \% \\
50.360 \% \\
50.864 \% \\
51.297 \% \\
55.619 \%\end{array}$ & 15.16 \\
\hline
\end{tabular}

Dari hasil diatas menunjukkan bahwa bawang hitam yang diberi perlakuan aging selama 4 minggu baik yang diekstraksi secara maserasi ataupun digesti memiliki aktivitas antioksidan lebih tinggi dibandingkan dengan sampel lainnya. Sedangkan bawang hitam yang diberi perlakuan aging selama 2 minggu memiliki nilai $\mathrm{IC}_{50}$ yang relatif tidak berbeda dengan aktivitas antioksidan sampel bawang putih. Dapat disimpulkan bahwa waktu aging dapat mempengaruhi aktivitas antioksidan.

\section{Kesimpulan}

Dari penelitian ini diperoleh hasil kadar abu yang tidak memenuhi syarat, sedangkan untuk parameter standar lainnya telah memenuhi persyaratan. Rendemen ekstrak yang diperoleh tidak terlalu menunjukkan perbedaan yang signifikan. Aktivitas antioksidan, bawang putih dan bawang hitam termasuk kedalam rentang aktivitas antioksidan sangat kuat, dengan nilai $\mathrm{IC}_{50}$ dibawah $50 \mathrm{ppm}$. Bawang putih maserasi memiliki nilai $\mathrm{IC}_{50}$ sebesar $28.422 \mathrm{ppm}$, bawang hitam 2 minggu maserasi $27.129 \mathrm{ppm}$ dan bawang hitam 4 minggu maserasi $13.041 \mathrm{ppm}$. Sedangkan pada bawang putih digesti 28.524 ppm, bawang hitam 2 minggu digesti $28.086 \mathrm{ppm}$ dan bawang hitam 4 minggu digesti $15.160 \mathrm{ppm}$. 


\section{E. Saran}

Perlu dilakukan penelitian lebih lanjut untuk menentukan waktu aging terbaik, serta penggunaan suhu yang tepat dan stabil pada saat proses aging.

\section{Daftar Pustaka}

[1] Amagase, H., B.L. Petesch, H. Matsuura, S. Kasuga, and Y. Itakura. 2001. Intake of garlic and bioactive components. Journal of Nutrition 131 (3): 955S - 962S.

[2] Andi, E.F., Made, A., Tutik, W., Nancy. D.Y., 2013. Kapasitas Antioksidan dan Inhibitor Alfa Glukosidase Ekstrak Umbi Bawang Dayak. Institut Pertanian Bogor.

[3] Badarinath A, Rao K, Chetty CS, Ramkanth S, Rajan T, \& Gnanaprakash K. A on In-vitro Antioxidant Methods :Comparisons, Correlations, and Considerations. International Journal of PharmTech Research, 2010 : 1276-1285. Ellmore, G. and R. Feldberg. 1994. Alliin lyase localization in bundle sheaths of garlic clove (Allium sativum). American Journal of Botany 81: 89-94. Choi, Duk Ju., et al. Physicochemical characteristics of black garlic (Allium sativum). J Korean Soc.Food Nutr. 2008. 37(4) : 465-71.

[4] Choi, S., H.S. Cha and Y.S. Lee. Physicochemical andAntioxidant Properties of Black Garlic. Molecules. 2014. $19: 16811-23$.

[5] Direktorat Jendral Pengawas Obat dan Makanan. 1986. Sediaan Galenik. Departemen Kesehatan RI : Jakarta.

[6] Hanny Farhana. 2018. Pengaruh Suhu dan Waktu Fermentasi Ekstrak Etanol Black Garlic (Allium sativum) Terhadap Aktivitas Antibakteri Staphylococcus aureus dan Escherichia coli.Universitas Jendral Achmad Yani, Cimahi.

[7] Hery, Winarsi. 2007. Antioksidan Alami dan Radikal Bebas. Yogyakarta : Kanisius.

[8] I Gusti A,. 2010. Optimasi Pembuatan Ekstrak Etanolik Kayu Secang (Caesalpinia sappan L.) Secara Digesti: Aplikasi Desain Faktorial. Universitas Sanata Dharma Yogyakarta. Molyneux P., 2004. The Use of Stable Free Radical Diphenylpicryl hydrazyl (DPPH) for Estimating Antioxidant Activity, J. Sci.Technol., 26(2), 211-219.

[9] Prayoga G. 2013. Fraksinasi UjiAktivitas Antioksidan dengan Metode DPPH dan Golongan Senyawa Kimia dari Ekstrak Teraktif Daun Sambang Darah (Excoecaria cochinchinensis Lour). Fakultas Farmasi Program Studi Sarjana Ekstensi Universitas Indonesia. Sultana.

[10] Rahmawati, R. 2012. Keampuhan Bawang Putih Tunggal (Bawang Lanang). Yogyakarta : Pustaka Baru Press.

[11] Rinaldi, M.A., dkk. 2014. Skrining Fitokimia Pada Ekstrak n- heksan, Kloroform dan daritanaman sapat (Mitragyna speciosa) Asal Babai Kalimantan Selatan. Sekolah tinggi Farmasi Borneo Lestarai Banjarbaru. Banjarbaju Selatan.

[12] Rouzni, Z. 2018. Pengaruh lama Aging Tehadap Sifat Fisik, Kimia, dan Aktivitas Antioksidan Produk Bawang Lanang. Jurnal Pangan dan Agroindusrti Vol. 6. Universitas Brawijaya Malang.

[13] Sadikin, M. 2001. Pelacakan Dampak Radikal Bebas terhadap Makromolekul. Kumpulan Makalah Pelatihan : Radikal Bebas dan Antioksidan dalam Kesehatan. Fakultas Kedokteran UI. Jakarta.

[14] Wang X., Jiao, F., Wang, Q.W., Wang, J., dkk., 2012. Aged Black Garlic Extract Induces Inhibition of Gastric Cancer Cell Growth In Vitro and In Vivo. The Journal of Molecular Medicine Reports.

[15] Wang, D., Feng, Y., Liu, J., Yan, J.,Wang, M., and Sasaki, Lu, C. 2010. Black Garlic (Allium sativum) Extracts Enhance The Immune System. Medicinal and Aromatic Plant Science and Biotechnology $4: 10$. 